\title{
THE EFFECT OF FARMER-PASTORALIST VIOLENCE ON INCOME: NEW SURVEY EVIDENCE FROM NigERIA’S MIDDLE BELT STATES
}

\section{Topher McDougal, TAlia Hagerty, LiSA InKs, Claire-Lorentz Ugo-IKe, Caitriona DoWD, StONE ConRoy, and DANiELOGABIELA}

Topher McDougal is Assistant Professor of Economic Development and Peacebuilding at the Joan B. Kroc School of Peace Studies, University of San Diego, California, USA. The corresponding author, he may be reached at tlm@sandiego.edu. Talia Hagerty is Research Fellow at the Institute for Economics and Peace, Sydney, Australia. She may be reached at thagerty@economicsandpeace.org. Lisa Inks is Director of Conflict Management Programs at Mercy Corps Nigeria. She may be reached at links@ng.mercycorps.org. Claire-Lorenz Ugo-Ike Ebele is Monitoring, Evaluation, and Learning Advisor at Mercy Corps Nigeria. She may be reached at cugoike@ng.mercycorps.org. Caitriona Dowd is Research Fellow at Mercy Corps Nigeria and a Ph.D. candidate at the University of Sussex. She may be reached at cdowd@ng.mercycorps.org. Stone Conroy is Conflict Management and Economic Development Fellow at Mercy Corps Nigeria. He may be reached at stone.conroy@gmail.com. Daniel Danladi Ogabiela is Monitoring, Evaluation, and Learning Officer at Mercy Corps Nigeria. He may be reached at dogabiela@ng.mercycorps.org.

\section{Abstract}

This study estimates the relationship between violent conflict and household income in four states of Nigeria's Middle Belt region (Benue, Kaduna, Nasarawa, and Plateau) where farmers and pastoralists routinely clash over access to farmland, grazing areas, stock routes, and water points for animals and households. Although relatively low in intensity, this form of violence is widespread, persistent, and arguably increasing in its incidence. We obtained data on income and household-level violence exposure from an original household survey administered in September 2014. Employing a negative binomial instrumental variables model, we find an inverse relation between violence and household incomes. Incomes could be increased by between 64 to 210 percent of current levels if violence related to farmer-pastoralist conflict in the four study states were reduced to near-zero. Cumulatively, we find that forgone income represents 10.2 percent of the combined official state domestic product in the study area. This is high when compared to the costs of conflict measured in other studies, even as our study takes account only of microeconomic costs. After incorporating an estimate of the size of the informal economy, the microeconomic cost of farmer-pastoralist conflict to the total economy is approximately 2.9 percent.

$\mathrm{T}$ his study seeks to understand the relationship between the violence that results from farmer-pastoralist conflict and household incomes in four states of the Middle Belt region of Nigeria, namely, Benue, Kaduna, Nasarawa, and Plateau. We created and administered an original, one-shot household survey designed to answer this research question: What is the effect of farmer-pastoralist violence on household income, both in general and by livelihood strategy? ${ }^{1}$

The analysis estimates income foregone as a result of violent farmer-pastoralist conflict. Our approach differs from typical accounting-cost attempts to sum the cost of conflict or benefits of peace. In contrast, we estimate household income that could be generated were violence reduced, as income loss is one of the many costs imposed on an economy as a result of violent conflict. We isolate the costs borne by households in terms of their ability to consume, save, and accumulate wealth as a result of lost income. Our work also generates microlevel data for use in a subsequent estimation of the macroeconomic cost of violent farmer-pastoralist conflict in a related study, also published in this issue. ${ }^{2}$

\section{Background}

Farmer-pastoralist conflict in the Middle Belt

Nigeria's ethnically and religiously diverse Middle Belt has experienced recurrent eruptions of violence over the past several decades. Disputes between pastoralists and farmers arise from disagreements over the use of land around farmland, grazing areas, stock routes, and access to water points for both animals and households. A range of interrelated factors underlie these disputes, including increased competition for land (arguably driven by desertification, climate change, and population growth), lack of clarity around the demarcation of pasture and stock routes, and the breakdown of traditional relationships and formal agreements between farmers and 
pastoralists. These conflicts undermine market development and economic growth by destroying productive assets, reducing production, preventing trade, deterring investment by private sector actors, and eroding trust and social cohesion. Because livelihood strategies in Nigeria are closely tied to identity and because access to services and opportunities can vary across identity groups, many farmer-pastoralist conflicts take on ethnic and religious hues and are exacerbated along identity lines. Most farmers, for instance, are Christian, while most pastoralists are Muslim (see Table 1 below). ${ }^{3}$

\section{Prior literature}

A number of studies have sought to measure the effects of violent conflict on income, often through a proxy measure of consumption. For instance, one study traces the impact of conflict on consumption at the village level in Burundi, finding that areas that experienced 25 war-related deaths or injuries subsequently saw a reduction of consumption growth of 13 percent compared to those which did not. Another study finds lower post-conflict household consumption in households that experienced high-intensity conflict within Rwanda in 1994. The effects of conflict on income may be channeled through different mechanisms, among which is displacement. Thus, one study analyzes data from displaced households in Colombia and finds that displacement limits the ability of households to generate new income. ${ }^{4}$

The ability of households to withstand the effects of violence on income and to absorb income shocks differs across conflict contexts and households. It may depend in part on wider economic conditions, market functionality, and the flexibility of households with regards to livelihood practices. As Patricia Justino notes:

A negative shock will result in losses in household utility and welfare if the household is not able to switch activities or no alternative activities exist. If the household is able to switch activities in order to take advantage of them [...] then losses may be small or the effect may even be positive. $^{5}$

The structure, nature, and functioning of the markets for goods and services supplied and demanded by an individual household suggest that even if an aggregate reduction in household incomes is observed across conflict contexts, some households will be more resilient and may even benefit from restructured markets. Aggregate figures may mask these countervailing tendencies, pointing to the need to disaggregate patterns by household characteristics and conditions as much as possible.
Nigeria's ethnically and religiously diverse Middle Belt has experienced recurrent eruptions of violence over the past several decades. Disputes between pastoralists and farmers arise from disagreements over the use of land around farmland, grazing areas, stock routes, and access to water points for both animals and households. This study estimates the effect of violence on forgone income.

Some studies have suggested that higher income levels correspond to a higher likelihood of being targeted in certain conflict contexts. For example, one paper analyzes the microeconomics of households affected by urban rioting in India and concludes that higher income per capita increases the likelihood of victimization through an opportunity cost mechanism. In common with the findings of other studies, the "target value" of a wealthy or high-income area may render it more vulnerable to violence, rather than less. The circular causation between violence and income indicates the need for an instrumental variable model to account for endogeneity. Finally, there is ample evidence at the microlevel that the experience of violent conflict can vary greatly between and among neighborhoods, households, and even family members, meaning that studies seeking to find relationships between violence and economic outcomes at the household level are most reliable when based on survey responses rather than imputing experience of violence based on, say, proximity to violent events. ${ }^{6}$

This study, then, adds to the sub-field of the cost of conflict literature dealing with income effects of violence. Its principal contribution is to evaluate the effects of violence in a non-civil war situation. However, it has other unique features as well. Existing research underscores the importance of empirical methods that account both for endogeneity in the relationship between income and violent conflict and derive measures of impact from methods sensitive to the variation in the effect of conflict within and across individuals, households, and communities. This study develops a model in line with these requirements in several ways. For one, it obtains disaggregated, household-level data, which is relatively uncommon-as mentioned, conflict researchers often presume that households experience more or less violence based on geographic or temporal proximity to violent events. The study also makes a unique contribution in applying these methods to a relatively understudied form and location of violence: Largely to the exclusion of the more quotidian farmer-pastoralist conflicts that characterize to a large extent violence dynamics in the Middle Belt region, and indeed large swathes of the African Sahel, media reports and academic studies of Nigerian violence have focused on petroleum extraction-related violence in the 
Table 1: Cross-tabulation of survey respondents by livelihood and religion

$\begin{array}{lcccc}\text { Livelihood } & \text { Muslim } & \text { Christian } & \text { Other } & \text { Total } \\ \text { Farming } & 262 & 643 & 9 & 914 \\ \text { Pastoralism } & 393 & 56 & 1 & 450 \\ \text { Mixed } & 25 & 2 & 0 & 27 \\ \text { Other } & 65 & 145 & 1 & 211 \\ \text { Total } & 745 & 846 & 11 & 1,602 \\ & & & & \\ \text { Note: } 1,602 \\ \text { questions regarding livelihood and religion. }\end{array}$

Niger delta region and, in recent years, violent extremism in the country's northeast. In contrast, the economic impact of the ubiquitous Middle Belt conflicts have only been indicated but not rigorously estimated. ${ }^{7}$

\section{Methods}

We use an original one-shot household-level cluster-sample survey $(n=1,607)$ administered in September of 2014 in rural areas of four Middle Belt states of Nigeria: Benue, Kaduna, Nasarawa, and Plateau. Previous research has found purposively designed surveys to generate better information on the broad range of effects of violent conflict on household income. In Nigeria, as in other contexts, existing recent surveys either do not collect data on income, do not collect data on violence experienced, or both (as in the case of the Demographic and Health Survey, DHS). As standard surveys tend to have some selection bias built into the sampling frame, we took care to aim for roughly equal representation between farmer and pastoralist households. For instance, it is likely that pastoralist communities are underrepresented in the DHS generally, due to the sampling frame being based on the Nigerian census. Sedentary settlements are privileged over temporary, nomadic ones, for obvious reasons. Moreover, there is some anecdotal evidence from Mercy Corps Nigeria staff that pastoralists who experience violence directed against their communities tend to move-whether deeper into the bush or across state lines. During the course of the administration of our survey, many pastoralist communities originally from Benue state had migrated recently to Nasarawa, where they felt more secure. ${ }^{8}$

Our survey was based on a 2-stage cluster sampling frame. The first stage selected the Local Government Areas (LGAs) to be sampled and determined how many clusters were in each sampled LGA. The second stage was done in the field, and required survey administrators to identify households in each community. Between these two stages, administrators identified specific communities to survey in each LGA by using randomly selected radii from the LGA centroid to capture a 20-degree section of each sampled LGA, assigning numbers to each community in the section, and then randomly selecting a number to identify a survey location. The survey design and sampling frame may be found in the Appendix. It is designed to be representative at the household level for rural areas in the study states. However, one weakness resides in the selection of villages within selected LGAs: While LGAs are selected on a population proportionate basis, villages have equal chances of being selected, privileging smaller villages disproportionately. Table 1 breaks out survey respondents by livelihood and religion.

Methodologically, we take a three-step approach. First, we run a 2-stage instrumental variable model to estimate the effect of violence on income. Second, we use a population attributable fraction (PAF) calculation to estimate the effect of a hypothetical reduction in violence to near-zero levels on total rural income. Third, we run adjusted predictions for each state of reducing violence to near-zero levels. This latter tactic will not only serve as a check on the PAF, but also break out results at a more local level.

\section{Empirical strategy}

At its base, this study seeks to assess the impact of farmer-pastoralist violence on income. But the relationship between the two variables is most often endogenous: While violence may depress income, high incomes may also attract violent attacks in the first place. Indeed, initial analyses from our survey data indicated that income and violence were significantly and positively associated with one another. We therefore use an instrumental variable (IV) approach. We chose to test as an IV candidate a binary variable indicating whether the INGO Mercy Corps had a programmatic presence in the surveyed community, since Mercy Corps' programs in the region are geared toward peacebuilding and violence reduction. Mercy Corps peacebuilding programs are often built around shared livelihoods projects, such as apiaries, raising the possibility that this choice of IV was poor. However, the variable proved both exogenous (i.e., not associated with the outcome of income) and relevant (i.e., associated with the main predictor of violence). However, it explains just 4.21 percent of the variation in violence, and its effect size is just around 38 percent of the interquartile range of the violence variable. These facts may signal that, while appropriate as an IV, it may not be strong enough to transmit a signal through regression 
Table 2: Summary statistics for two outcome variables (in Naira)

$\begin{array}{lcc}\text { Statistic } & \begin{array}{c}\text { Last month's } \\ \text { income }\end{array} & \begin{array}{c}\text { Yearly } \\ \text { income }\end{array} \\ \text { Observations } & 1,570 & 1,568 \\ \text { Mean } & 111,994 & 1,755,363 \\ \text { Variance }\left(\times 10^{9}\right) & 3,600 & 1,580,000 \\ \text { Skewness } & 39 & 39 \\ \text { Minimum } & 150 & - \\ \text { P25 } & 20,000 & 200,000 \\ \text { P50 } & 40,000 & 360,000 \\ \text { P75 } & 70,000 & 720,000 \\ \text { Maximum } & 75,000,000 & 1,560,000,000\end{array}$

residuals in the presence of many control variables. ${ }^{9}$

Our second step is made of (a) a 1st-stage ordinary least squares (OLS) model predicting the violence variable and instrumented by Mercy Corps' program intervention, and (b) a 2nd-stage negative binomial estimator estimating monthly income as a function of violence and residuals from the 1st-stage model. Written as simultaneous equations, the IV model takes the form:

$$
\begin{gathered}
V_{i}=\alpha_{0}+\alpha_{1} M C+\gamma_{i} X_{i n}+\ldots+\gamma_{i n} X_{i n}+\varepsilon_{1} \\
E\left(I N C_{i}\right)=\mu_{i}=\exp \left(\beta_{0}+\beta_{1} V_{i}+\beta_{2} \operatorname{Res}_{V_{i}}+\right. \\
\left.\delta_{1} X_{i 1}+\ldots \delta_{i n} X_{i n}+\varepsilon_{2}\right)
\end{gathered} .
$$

The first equation models felt violence for household $i\left(V_{i}\right)$ as a function of $M C$, the presence of Mercy Corps, and a given set of controls $X_{i 1}$ to $X_{i n}$. The second, negative binomial, equation models last month's income of household $i\left(I N C_{i}\right)$ as a function of felt violence $V_{i}$. The latter is appropriate given that the outcome variable is extremely right-skewed and its variance is far greater than its mean (see Table 2).

\section{Variables: Outcome, predictor, controls}

The outcome variable is household income. We examine income because it is a useful indicator for microeconomic development: Income is the basis of Gross National Income (GNI), raising incomes is a goal of economic development, its absence is a globally accepted indicator of poverty, and, despite difficulties in data collection, income is relatively straightforward to measure. In addition, it has been shown that low incomes reduce the opportunity cost of engaging in violence, implying that raising incomes is a critical peacebuilding activity. We considered examining expenditure, which would arguably have fed more naturally into this study's macroeconomic counterpart. But expenditure might rise in crises, when households may need to dip into savings or even liquidate assets. Such expenditure may boost GDP in the short term, but it would be an unsustainable coping mechanism in the face of financial stress. Returning to income, there are two possible survey questions from which to derive the measure of household income, one asking for 'income reported in the last month,' the other for 'income in the last year' (see Table 2). We chose to work with the former as the belief that it is less prone to generalizations and therefore possibly more sensitive to the effects of recent violence. ${ }^{10}$

The average monthly income per household in our sample was 111,994 Naira, or roughly USD680, while the mean yearly reported income was 1,755,363 Naira, or about 146,000 Naira per month. The World Bank reports that the 2013 Gross National Income (GNI) per capita in Nigeria is 446,252 Naira per year, or around 37,200 Naira monthly, implying that on average, households have the approximate equivalent of three income-earning members. ${ }^{11}$

Regarding the predictor variable, we hoped to use a single variable to represent violence at the household level. But the common proxy of household fatalities seemed too insensitive, conceptually and statistically, not capturing nuances of experienced violence. Violence that causes injuries without fatalities, as well as threats of violence that provoke behavioral changes or restrict geographic access, could very conceivably affect household income. Therefore, we constructed a single predictor variable using the first eigenvector of a principal components analysis (PCA) of binary variables (household deaths, household injuries in the past year, and access impairment to various amenities due to threat of violence), categorical variables (degree to which access was impaired for certain amenities), and the sum of integer count variables (numbers of dead and injured due to farmer-pastoralist conflict). Data for all of these variables were collected individually in the administered survey. The primary component encapsulates 52.6 percent of the total variation in the violence variables (Table 3).

Names, types, and descriptions of household-level control variables employed are listed in an endnote. ${ }^{12}$ We also control for state and cluster of each household. ${ }^{13}$

\section{Population attributable fraction (PAF)}

Following the first step model estimation, to estimate the total household income that would be gained if farmer-pastoralist violence levels were brought down to zero we then employ the epidemiological concept of a population attributable fraction 
Table 3: Eigenvector of the violence PCA and their proportion of violence explained

$\begin{array}{ccccc}(1) & (2) & (3) & (4) & (5) \\ & & & & \\ 1 & 3.15371 & 1.96692 & 0.5256 & 0.5256 \\ 2 & 1.18679 & 0.55483 & 0.1978 & 0.7234 \\ 3 & 0.63196 & 0.19141 & 0.1053 & 0.8287 \\ 4 & 0.44055 & 0.06488 & 0.0734 & 0.9022 \\ 5 & 0.37567 & 0.16436 & 0.0626 & 0.9648 \\ 6 & 0.21131 & - & 0.0352 & 1.0000\end{array}$

Note: (1) Component; (2) eigenvalue; (3) difference; (4) proportion; (5) cumulative proportion.

(PAF), or etiologic fraction. PAF is usually used to determine the proportion of disease incidence that is attributable to exposure to the risk factor. Here we want to estimate the income reduction that is attributable to exposure to violence. ${ }^{14}$

The PAF for adjusted predictions is often defined as

$$
P A F=\frac{\operatorname{Pr}(E \mid D) \times\left(R R_{\text {adjusted }}-1\right)}{R R_{\text {adjusted }}},
$$

where $\operatorname{Pr}(E \mid D)$ represents the prevalence of exposure given the disease (in our case, the decile exposure to violence for each household), and $R R_{\text {adjusted }}$ represents the adjusted relative risk of disease (here, the adjusted prediction of income as a function of violence). To illustrate the concept, take the example of smoking (exposure) and lung cancer (disease). In this scenario, $\operatorname{Pr}(E \mid D)$ represents the probability of being a smoker, given that one has lung cancer. In effect, this term identifies the total population, in proportional terms, that could be affected if smoking were eliminated. $\mathrm{RR}_{\text {adjusted }}$ in this scenario represents the ratio of the probability of having cancer given smoking to the probability of having cancer given nonsmoking, controlling for age, genetic predisposition, etc. It is, in other words, the percentage increase in risk of cancer associated with smoking. Conversely, $\left(R_{\text {adjusted }}-1\right) / R_{\text {adjusted }}$ then is the percentage reduction in adjusted risk of lung cancer given the elimination of smoking. Putting the two terms together yields the proportion of lung cancers among the smoking population that would be prevented with the elimination of smoking. The formulation, however, assumes that no lung cancers among the nonsmoking population could be prevented (e.g., through the removal of second-hand smoke), using the unexposed population as a baseline. ${ }^{15}$

In our application of the PAF, we likewise assume that the decile of households experiencing the least amount of farmer-pastoralist violence is our baseline or standard of comparison. Any decline in adjusted income in other deciles is then attributed to farmer-pastoralist violence. Equation (2) tends to overestimate the PAF as it assumes perfect additivity of the effects of variables when included in a single model, that is, $E_{A}+E_{B}=E_{(A+B)}$. To mitigate that risk, we implemented a statistical formulation allowing for $E_{A}+E_{B}>E_{(A+B)}$. Returning to the smoking example, we might find that the removal of smoking reduces the total number of lung cancers by, say, 60 percent, but that elimination of smog would be predicted to reduce lung cancers by 30 percent. The PUNAF module does not assume that all lung cancers prevented by the elimination of smoking are mutually exclusive of those prevented by the elimination of smog - many people are exposed to both, and the elimination of one would suffice to prevent their would-be lung cancer. Thus, the total percentage reduction of lung cancers by the elimination of both smog and smoking is likely less than $(1-(1-0.6) \times(1-0.3)) \times 100=72$ percent. $^{16}$

In this case, the PAF function will estimate household income by summing the adjusted predictions of income across all decile-violence groups of households. This is akin to taking the integral of the (presumably) downward-sloping adjusted predictions curve of income as a function of decile-violence exposure. The PAF function then estimates the proportion of total income in the study area that is unattributable to the predictor variable. Therefore, the adjusted prediction for the tenth decile-distance group of households is assumed, ceteris paribus, to be the baseline level of income that would exist in a hypothetical alternative scenario in which all households in the study area are lowered to a level of violence exposure equivalent to that felt by the least affected 10 percent of households. Any dip below that baseline level of income is then considered to be attributable to the presence of violence related to the farmer-pastoralist conflict. In effect, the PAF function ascribes the adjusted baseline level of income to each of the household decile groups and then subtracts out the sum of the attributed values. The remainder is treated as the numerator in equation (2) and normalized by the sum of adjusted predictions across decile-violence groups to obtain a proportion. This proportion would represent the presumed fraction of total hypothetical income (in a peaceful scenario) that violence has destroyed.

\section{Results}

Single-stage negative binomial models predicting income as a function of violence yield either weak, statistically insignificant coefficients or strong positive coefficients, depending on the control scheme (Table 4). This was foreseen in the research design phase, as discussed above. In the 2-stage models, 
Table 4: Single-stage negative binomial models predicting monthly income as a function of violence

\begin{tabular}{|c|c|c|c|c|c|c|}
\hline Variables & (1) hh046 & (2) hh046 & (3) $h h 046$ & (4) hh046 & (5) hh046 & (6) hh046 \\
\hline Violence PCA component 1 & $\begin{array}{c}-0.117 \\
(-0.108)\end{array}$ & $\begin{array}{c}\mathbf{0 . 0 7 0 4} * * * \\
(0.0242)\end{array}$ & $\begin{array}{c}-0.101 \\
(-0.0650)\end{array}$ & $\begin{array}{c}\mathbf{0 . 0 6 9 5} * * * \\
(0.0242)\end{array}$ & $\begin{array}{c}0.0130 \\
(0.0219)\end{array}$ & $\begin{array}{c}0.0167 \\
(0.0228)\end{array}$ \\
\hline Controls & No & Yes & No & Yes & No & Yes \\
\hline State categorical control & No & No & Yes & Yes & No & No \\
\hline Cluster categorical control & No & No & No & No & Yes & Yes \\
\hline Constant & $\begin{array}{c}\text { 11.67*** } \\
(0.337)\end{array}$ & $\begin{array}{c}\text { 9.139*** } \\
(1.500)\end{array}$ & $\begin{array}{c}12.35 * * * \\
(0.586)\end{array}$ & $\begin{array}{c}8.577 * * * \\
-0.252 * * *\end{array}$ & $\begin{array}{c}\text { 10.46*** } \\
(0.182)\end{array}$ & $\begin{array}{c}\text { 9.239*** } \\
(1.170)\end{array}$ \\
\hline Ln alpha & $\begin{array}{c}\mathbf{0 . 6 2 4} * * \\
(0.246)\end{array}$ & $\begin{array}{c}-\mathbf{0 . 2 3 6 * * *} \\
(-0.0532)\end{array}$ & $\begin{array}{c}\mathbf{0 . 4 8 7} * * * \\
(0.149)\end{array}$ & $\begin{array}{c}(-0.0569) \\
(1.193)\end{array}$ & $\begin{array}{c}0.0581 \\
(0.0467)\end{array}$ & $\begin{array}{c}-\mathbf{0 . 3 4 2 * * *} \\
(0.0444)\end{array}$ \\
\hline Observations & 1,448 & 1,135 & 1,448 & 1,135 & 1,448 & 1,135 \\
\hline Number of strata & 39 & 39 & 39 & 39 & 39 & 39 \\
\hline F-value & 1.179 & 4.817 & 1.903 & 5.478 & 6.267 & 4.761 \\
\hline p-value & 0.278 & 0 & 0.108 & 0 & 0 & 0 \\
\hline
\end{tabular}

Note: Standard errors in parenthesis; ${ }^{* * *} \mathrm{p}<0.01$; ${ }^{* *} \mathrm{p}<0.05$; ${ }^{*} \mathrm{p}<0.10$.

Table 5: Endogeneity-controlling 2-stage (OLS/negative binomial) models predicting monthly income as a function of violence

\begin{tabular}{|c|c|c|c|c|c|c|}
\hline Variables & (1) $h h 046$ & (2) hh046 & (3) $h h 046$ & (4) hh046 & (5) $h h 046$ & (6) hh046 \\
\hline Violence PCA component 1 & $\begin{array}{c}-\mathbf{0 . 9 3 2} * * \\
(-0.445)\end{array}$ & $\begin{array}{c}-\mathbf{0 . 6 2 6} * * \\
(-0.249)\end{array}$ & $\begin{array}{c}-\mathbf{0 . 3 6 6} * * * \\
(-0.115)\end{array}$ & $\begin{array}{l}-\mathbf{0 . 3 0 8} * \\
(-0.170)\end{array}$ & $\begin{array}{c}0.199 \\
(0.196)\end{array}$ & $\begin{array}{l}-0.169 \\
(0.340)\end{array}$ \\
\hline Residuals & $\begin{array}{c}\mathbf{0 . 8 5 3} * * \\
(0.377)\end{array}$ & $\begin{array}{c}\mathbf{0 . 6 9 6 * * *} \\
(0.250)\end{array}$ & $\begin{array}{c}\mathbf{0 . 2 7 4 * *} \\
(0.118)\end{array}$ & $\begin{array}{c}\mathbf{0 . 3 7 8} * * \\
(0.171)\end{array}$ & $\begin{array}{c}0.217 \\
(0.185)\end{array}$ & $\begin{array}{c}0.185 \\
(0.341)\end{array}$ \\
\hline Controls & No & Yes & No & Yes & No & Yes \\
\hline State “fixed effects” & No & No & Yes & Yes & No & No \\
\hline Cluster “fixed effects” & No & No & No & No & Yes & Yes \\
\hline Constant & $\begin{array}{c}\text { 11.62*** } \\
(0.302)\end{array}$ & $\begin{array}{c}\text { 9.457*** } \\
(1.497)\end{array}$ & $\begin{array}{c}12.40 * * * \\
(0.583)\end{array}$ & $\begin{array}{c}\mathbf{8 . 8 5 9} * * * \\
(1.191)\end{array}$ & $\begin{array}{c}\text { 10.32*** } \\
(0.217)\end{array}$ & $\begin{array}{c}\text { 9.096**** } \\
(1.255)\end{array}$ \\
\hline Ln alpha & $\begin{array}{c}\mathbf{0 . 5 9 4 * *} \\
(0.232)\end{array}$ & $\begin{array}{c}-\mathbf{0 . 2 3 6} * * * \\
(-0.0532)\end{array}$ & $\begin{array}{c}\mathbf{0 . 4 8 3} * * * \\
(0.149)\end{array}$ & $\begin{array}{c}-\mathbf{0 . 2 5 2 * * * *} \\
(-0.0569)\end{array}$ & $\begin{array}{c}0.0584 \\
(0.0466)\end{array}$ & $\begin{array}{c}-\mathbf{0 . 3 4 2 * * *} \\
(0.0444)\end{array}$ \\
\hline Observations & 1,444 & 1,135 & 1,444 & 1,135 & 1,444 & 1,135 \\
\hline Number of strata & 39 & 39 & 39 & 39 & 39 & 39 \\
\hline F-value & 3.024 & 4.817 & 3.223 & 5.478 & 5.829 & 4.761 \\
\hline p-value & 0.0489 & 0 & 0.00673 & 0 & 0 & 0 \\
\hline
\end{tabular}

Note: Standard errors in parenthesis; ${ }^{* * *} \mathrm{p}<0.01$; ${ }^{* *} \mathrm{p}<0.05$; ${ }^{*} \mathrm{p}<0.10$.

however, the coefficients for the first component of the violence PCA are universally negative and statistically significant at the $\mathrm{p}<0.10$ level for Models 1 to 4 (Table 5). Household controls and state- and cluster-level "fixed effects" depress the absolute values of the coefficients, with the smallest effect size exhibited in Model 6, in which both household controls and cluster-level "fixed effects" are included. In Models 1 to 4, the residuals term for the first-stage model predicting violence (proxied using our PCA first component of reported experience of violence) as a function of Mercy Corps' programmatic intervention is statistically significant at the $\mathrm{p}<0.05$ level, indicating the appropriateness of an IV approach. Models 5 and 6 do not exhibit statistical significance, possibly due to the previously mentioned reason that the IV may not exert a strong enough effect to be "heard" through the numerous controls in the 1st stage. In other words, increased specificity in control variables may "mute" the effect of the IV.

Consequently, all of the relevant models yield population attributable fractions (PAFs) that are negative. Negative PAFs indicate that if violence is hypothetically reduced, the total income of respondents would be greater. PAFs are calculated 
Table 6: Income change coefficients for violence reduction (in Naira)

$\begin{array}{cccc}\text { Model } & \text { Estimate } & 95 \% \text { LB } & 95 \% \text { UB } \\ 1 & 354.37 & 6,777,650.10 & -0.98 \\ 2 & 45.35 & 13,412.44 & -0.84 \\ 3 & 2.01 & 6.88 & 0.15 \\ 4 & 2.10 & 17.81 & -0.49 \\ 5 & 0.64 & 4.03 & -0.47 \\ 6 & 0.64 & 15.21 & -0.83\end{array}$

Table 7: Adjusted predictions of income changes due to hypothetical violence reduction by state (in Naira)

Predictions on Model 3

$\begin{array}{lcc}\text { State } & \begin{array}{c}\text { Predicted } \\ \text { average income } \\ \text { change (Naira) }\end{array} & \begin{array}{c}\text { Predicted } \\ \text { average income } \\ \text { change (\%) }\end{array} \\ \text { Benue } & 406,058 & 154 \\ \text { Kaduna } & 66,171 & 89 \\ \text { Nasarawa } & 192,857 & 190 \\ \text { Plateau } & 151,905 & 177 \\ \text { Total } & 204,796 & 137\end{array}$

Predictions on Model 4

$\begin{array}{lcc}\text { Benue } & 88,710 & 119 \\ \text { Kaduna } & 84,779 & 71 \\ \text { Nasarawa } & 110,690 & 145 \\ \text { Plateau } & 193,304 & 136 \\ \text { Total } & 106,601 & 107\end{array}$

Table 8: Adjusted predictions of income changes due to hypothetical violence reduction by livelihood (in Naira; based on Model 4)

$\begin{array}{lcc}\text { Livelihood } & \begin{array}{c}\text { Predicted } \\ \text { average income } \\ \text { change (Naira) }\end{array} & \begin{array}{c}\text { Predicted } \\ \text { average income } \\ \text { change (\%) }\end{array} \\ \text { Farming } & 108,901 & 108 \\ \text { Pastoral } & 46,754 & 101 \\ \text { Mixed } & 160,649 & 116 \\ \text { Trading/other } & 82,693 & 96 \\ \text { Total } & 120,223 & 109\end{array}$

for each Table 5 Model, which, when multiplied by -1 , then yield income change coefficients for hypothetically reduced farmer-pastoralist violence over all four states to the minimum value reported (Table 6). These coefficients can be multiplied further by the average rural income to yield the predicted total additional income earned due to the absence of violence. For instance, Model 3, in which we have employed categorical controls at the state level, predicts that the absence of violence would yield a 201 percent increase in rural incomes. Model 6, which includes specific control variables at the household level and categorical controls at the cluster level, yields the smallest coefficient, indicating that reducing violence to minimal values across all four states would yield a 64 percent increase in total rural income.

Models 3 (using state-level "fixed effects") and 4 (which uses specific household controls as well as categorical controls at the state level), can yield adjusted predictions of income changes due to violence reduction by state, as shown in Table 7. These average hypothetical percentage income increases are inferior to, but of the same order of magnitude as, the income change coefficients for Models 3 and 4 in Table 5. The increases in income presented in Table 7 are over and above current incomes: For example, the estimated income increase of 119 percent in Benue, based on Model 4, represents 2.19 times the state's current income.

Adjusted predictions may also be broken out by livelihood category. This categorization yields the figures in Table 8 . The total figures differ slightly from those in Table 7 because control variables describing income from various livelihood strategies (i.e., hh042, hh043, and hh044) had to be dropped to allow specification of the livelihood strategy itself (i.e., hh045).

\section{Conclusion}

We have demonstrated that farmer-pastoralist conflict in rural areas of Nigeria's Middle Belt states may adversely affect household incomes, and quite dramatically so. At least three methodological caveats should be noted, however. The first concerns the IV. If it is correct that the IV employed was not strong enough to keep the 1st-stage residuals term statistically significant, we could reason that the effect sizes seen in Table 5, Models 5 and 6 might not be unreasonable. Indeed, they follow the trend of decreasing effect sizes as more control variables and "fixed effects" are added, even if their standard errors do not contract enough to keep them significant.

There is reason, however, to believe that "fixed effects" at the state level are superior to those at the cluster level. It is well appreciated in the economic geography literature that violent events have spatial spill-over effects: If one family is attacked, word spreads and friends and neighbors alter their behavior in response. This clustered response can cause spatial auto-correlation in the outcome variable, meaning that incomes in an entire cluster could be depressed due to generalized behavior modifications (e.g., households deciding not to let their cattle graze freely, or not to cultivate more distant fields, 
Table 9: Estimated total rural income costs of conflict (in '000s) by state due to hypothetical violence reduction

\begin{tabular}{|c|c|c|c|c|c|c|c|}
\hline \multirow[b]{2}{*}{ State } & \multirow[b]{2}{*}{$\begin{array}{l}\text { No. of rural } \\
\text { households }\end{array}$} & \multicolumn{3}{|c|}{ Est. cost to rural income ('000s) } & & \multicolumn{2}{|c|}{ Losses as \% of } \\
\hline & & Currency & Model 3 & Model 4 & $\begin{array}{l}\text { State GDP } \\
\text { 2014* }\end{array}$ & $\begin{array}{c}\text { State } \\
\text { GDP** }\end{array}$ & $\begin{array}{c}\text { Formal \& informal } \\
\text { economy** }\end{array}$ \\
\hline Benue & 340,632 & $\begin{array}{l}\text { Naira } \\
\text { USD }\end{array}$ & $\begin{array}{c}1,659,797,389 \\
10,108,166\end{array}$ & $\begin{array}{c}362,609,947 \\
2,208,295\end{array}$ & $\begin{array}{c}3,612,921,757 \\
22,002,693\end{array}$ & 9.1 & 2.6 \\
\hline Kaduna & 394,765 & $\begin{array}{l}\text { Naira } \\
\text { USD }\end{array}$ & $\begin{array}{c}313,464,164 \\
1,908,997\end{array}$ & $\begin{array}{c}401,614,900 \\
2,445,835\end{array}$ & $\begin{array}{c}5,439,384,242 \\
33,125,850\end{array}$ & 6.9 & 2.0 \\
\hline Nasarawa & 115,659 & $\begin{array}{l}\text { Naira } \\
\text { USD }\end{array}$ & $\begin{array}{c}267,667,675 \\
1,630,096\end{array}$ & $\begin{array}{c}153,627,754 \\
935,593\end{array}$ & $\begin{array}{c}1,590,654,072 \\
9,687,083\end{array}$ & 8.8 & 2.5 \\
\hline Plateau & 255,555 & $\begin{array}{l}\text { Naira } \\
\text { USD }\end{array}$ & $\begin{array}{c}465,840,239 \\
2,836,967\end{array}$ & $\begin{array}{c}592,796,202 \\
3,610,129\end{array}$ & $\begin{array}{c}2,712,849,466 \\
16,521,253\end{array}$ & 17.9 & 5.2 \\
\hline Total & $1,106,611$ & $\begin{array}{l}\text { Naira } \\
\text { USD }\end{array}$ & $\begin{array}{c}2,706,769,467 \\
16,484,226\end{array}$ & $\begin{array}{c}1,510,648,803 \\
9,199,851\end{array}$ & $\begin{array}{c}13,355,809,536 \\
81,336,880\end{array}$ & 10.2 & 2.9 \\
\hline
\end{tabular}

Notes: * Based on 2007 estimates from the Canback Global Income Distribution Database (C-GIDD), updated for GDP growth and inflation to 2014. ** Based on Model 4 estimates.

for fear of attack). The household violence variable will not capture the full range of security perceptions. In this case, cluster-level fixed effects, or introduction of a categorical cluster control variable, will attribute any resulting generally low incomes to unobserved cluster characteristics that remain immutable. ${ }^{17}$

The second caveat concerns the limitations of all one-shot surveys, this one included. The lack of panel data implies that the income effects estimated in the above models demonstrate correlation but not Granger causation. Moreover, this particular survey was not nearly as large as, say, the Demographic and Health Survey for the country.

Third, our 2nd-stage sampling method may lead to positively or negatively biased results. Smaller villages are likely to be disproportionately represented. If smaller villages are also more likely to suffer farmer-pastoralist violence, we would have overestimated the general effect. If they are less likely to suffer such violence, we would have underestimated the effect.

Given a few contextual facts regarding population and its split along rural/urban lines, we are able to extrapolate from the adjusted predictions at the household level to the total microeconomic costs of farmer-pastoralist conflicts in the study states. According to the 2013 National Demographic and Health Survey (DHS) of the National Population Commission, the population of Nigeria is 57.9 percent rural and 42.1 percent urban, or $93,589,088$ people in rural areas according to the
World Bank. An earlier National Population Commission survey reports similar national statistics (62.8 percent rural and 37.2 percent urban), but also reveals that the four study states have largely rural populations: 81.4 percent rural in Benue, 65.5 percent in Kaduna, 81.3 percent in Nasarawa, and 65.28 percent in Plateau. $^{18}$

According to the 2006 census, Benue state has 4,253,641 people, Kaduna 6,066,562, Nasarawa 2,040,097, and Plateau $3,178,712$. Our survey-adjusted means for household size for those states are 10.16, 10.07, 14.34, and 8.12, respectively. Multiplying the state populations by the respective state rural population percentages gives the rural population. We then divide that by the average rural household size by state to obtain total rural households in each of the study states. If we conservatively assume that farmer-pastoralist conflict only has a direct effect on the incomes of rural households, then we can estimate the total income effect of a hypothetical reduction in farmer-pastoralist violence based on the projections in Table 7. Table 9 gives these estimations by state and in total.

The aggregate microeconomic costs of violence according to this estimation method totals around USD9.2 billion annually. This sum represents roughly 10.2 percent of the combined official state domestic products in the study area. This result is high when compared to the costs of conflict measured in other studies, even as our study takes into account only the microeconomic costs (i.e., excluding macroeconomic ripple effects). The total costs of outright civil war to the Sri 
Lankan economy, for instance, has been estimated at around 11 to 16 percent of that country's GDP over the period 1983-1996. ${ }^{19}$

However, a few considerations make our estimates at least plausible. For one, we have estimated the virtual elimination of a widespread form of violence, rather than just modeling the effect of a civil war on an economy. Second, the percentages we have estimated are based on numerators and denominators that are separately obtained: Other cost of conflict studies use official GDP only and therefore are internally consistent. In our case, the numerator (income losses) is estimated from survey data, while the denominator is the estimated official GDP. The latter may vastly underestimate the size of the real economy. One study estimates that Nigeria's informal economy represents 71.2 percent of total output in 2010. This implies that the formal sector is only 28.8 percent of the total. Depending on which variable is chosen from the survey (monthly or yearly estimated income), Nigeria's per capita GNI as a percentage of mean reported income is between 25.7 and 33.2 percent. If we then adjust the percentages reported in Table 9 to account for the informal economy, then the microeconomic cost of farmer-pastoralist conflict to the total economy hovers at around 2.9 percent (10.2 percent $\times$ $0.2882) .^{20}$

In sum, we have demonstrated that the microeconomic effects of farmer-pastoralist violence, in terms of household income lost, are mostly likely not trivial. Farmer-pastoralist conflicts stretch across the continent, intersecting with both urban violence between religious groups (such as riots in the city of Jos on repeated occasions) and violent extremism (such as in the case of Boko Haram in northeastern Nigeria, or the Lord's Resistance Army, formerly of northern Uganda). Furthermore, climate change may make this type of livelihood conflict more common. ${ }^{21}$ Policymakers in Nigeria and across the Sahel may wish to pay greater attention to resolving such disputes in the knowledge of the tolls they take on their constituents' wellbeing.

\section{Notes}

This study is part of a UK Department for International Development (DFID)-funded Mercy Corps program entitled "Conciliation in Nigeria through Community-Based Conflict Management and Cooperative Use of Resources” (CONCUR). We thank DFID and Mercy Corps for their support. The authors gratefully acknowledge the logistical support and insights of the entire Mercy Corps Nigeria team, including Tog Gang, Theophilus Agada, John Ebile, Fatima Madaki, Tahiru Ahmadu, Abdullahi Gambo, Peret Peter, Israel Okpe, and Halima Babaji. Special thanks go to the dedicated members of the Research Steering Committee, who have guided this study:
Saleh Momale, Mohammed Bello Tukur, Chris Kwaja, Job Jack Bot, Ibrahim Safiyanu, Jerry Agada, and Akase P. Sorkaa. We are also indebted to Mercy Corps staff Beza Tesfaye, Rebecca Wolfe, and Madeline Rose, as well as DFID economist Andy Hinsley and two anonymous reviewers for their valuable comments.

1. The Middle Belt is an informal term that encompasses states along Nigeria's North-South divide, and overlaps with the North-Central geopolitical zone.

2. Related study: See McDougal, et al. (2015).

3. Competition for land: Benjaminsen, Alinon, Buhaug, and Buseth (2012); Hendrix and Glaser (2007); Odoh and Chigozie (2012); Sayne (2011). Breakdown of traditional relationships: Blench (2010). Exacerbated along lines of identity: Mohammed (undated); Sulaiman, Ja`afar-Furo, Nasiru, Haruna, and Ochi (2011).

4. Burundi: Verwimp and Bundervoet (2008). Rwanda: Serneel and Verpoorten (2012). Colombia: Ibánez and Moya (2006).

5. Justino (2011, p. 14).

6. Urban riots in India: Gupte, Justino, and Tranchant (2014). In common with other studies: Hegre, Østby, and Raleigh (2009, p. 600). Ample microlevel evidence: Justino, Brück, and Verwimp (2013).

7. Researchers often presume: For instance, Hegre, et al. (2009); McDougal (2011). Middle Belt region: Cf. Higazi (2013); Mohammed (undated); Sulaiman, et al. (2011). Sahel: Jones-Casey and Knox (2011). Niger delta: Hazen and Horner (2007); Hunt (2006); Obi (2010); Watts (2007). Extremism in the northeast: Aghedo and Osumah (2012); Onuoha (2010). Ubiquitous conflicts: Mohammed (undated).

8. Previous research: Brück, Justino, Verwimp, and Avdeenko (2010).

9. Endogenous relation: See, e.g., André and Plateau (1998).

10. Quote: World Bank (2011, p. 78). Macroeconomic counterpart: McDougal, et al. (2015).

11. World Bank (2014).

12. Name, type, and description of control variables used at the household level: hh019 Integer hh020 Integer hh021 Integer hh022 Integer hh023 Integer hh024 Integer

hh025 Integer hh026 Integer hh027 Integer hh029 Integer hh030 Integer hh031 Categorical hh033 Categorical

Household size

Number of adults

Number of adult men

Number of adult women

Number of adults w/ primary education

Number of adults w/ secondary education

Number of children

Number of boys

Number of girls

Number of household girls in school

Number of household boys in school

Ethnicity

Religion 
hh035 Integer Number of months in this community hh036 Binary Ever migrated?

hh042 Ordinal (1-5) Amount of income from farming hh043 Ordinal (1-5) Amount of income from pastoralism hh044 Ordinal (1-5) Amount of income from trading hh045a Categorical Livelihood strategy (farming, mixed, pastoralism, trading/other)

13. The Stata command menbreg is not compatible with survey adjustments, so we are unable to use true fixed effects at the state or cluster levels. Therefore, we run the nbreg command with the categorical control variables of state and cluster, which, aside from the unfortunate effect of decreasing the degrees of freedom more than does the standard fixed effects approach, accomplishes a similar goal.

14. Usual use of PAF: Greenland and Drescher (1993); Last (2001, p. 137).

15. Adjusted relative risk: See, e.g., Doidge, Segal, and Gospodarevskaya (2012).

16. Additivity: Walter (1976; 1983). Statistical formulation: Greenland and Drescher (1993) as implemented in Stata's PUNAF module (Newson, 2012).

17. Spatial spill-over effects: Maystadt, De Luca, Sekeris, and Ulimwengu (2014); Tollefsen (2012).

18. DHS: Nigeria National Population Commission (2013, p. 9). World Bank: World Bank (2014). State populations: Nigeria National Population Commission (2006).

19. Sri Lanka: Lindgren (2005, p. 12).

20. Size of informal economy: Ogbuabor and Malaolu (2013).

21. Climate change: Benjaminsen, et al. (2012); Hendrix and Glaser (2007); Odoh and Chigozie (2012); Sayne (2011).

\section{References}

Aghedo, I. and O. Osumah. 2012. "The Boko Haram Uprising: how should Nigeria respond?” Third World Quarterly. Vol. 33, No. 5, pp.853-869.

http://dx.doi.org/10.1080/01436597.2012.674701

André, C. and J.-P. Plateau. 1998. "Land Relations under Unbearable Stress: Rwanda Caught in the Malthusian Trap.” Journal of Economic Behavior and Organization. Vol. 34, No. 1, pp. 1-47. http://dx.doi.org/10.1016/S0167-2681(97)00045-0

Benjaminsen, T.A., K. Alinon, H. Buhaug, and J.T. Buseth. 2012. "Does Climate Change Drive Land-Use Conflicts in the Sahel?” Journal of Peace Research. Vol. 49, No. 1, pp. 97-111. http://dx.doi.org/10.1177/0022343311427343

Blench, R. 2010. "Conflict Between Pastoralists and Cultivators in Nigeria.” Review paper for Department for I n t e rnationa l D e velopment, U K . www.rogerblench.info/.../Nigeria/Pastoralism/Fadama\%2 0II\%20paper.pdf [accessed 20 March 2015].

Doidge, J.C., L. Segal, an E. Gospodarevskaya. 2012. “Attributable Risk Analysis Reveals Potential Healthcare
Savings from Increased Consumption of Dairy Products.” The Journal of Nutrition: Methodology and Mathematical Modeling. Vol. 142, pp. 1772-1780.

http://dx.doi.org/10.3945/jn.111.154161

Greenland, S. and K. Drescher. 1993. "Maximum Likelihood Estimation of the Attributable Fraction from Logistic Models.” Biometrics. Vol. 49, pp. 865-872. http://dx.doi.org/10.2307/2532206

Gupte, J., P. Justino, and J.-P. Tranchant. 2014. “Households Amidst Urban Riots: The Economic Consequences of Civil Violence in India.” Journal of Conflict Resolution. Vol. 58, No. 8, pp. 1445-1473. http://dx.doi.org/10.1177/0022002714547886

Hazen, J.M. and J. Horner. 2007. "Small Arms, Armed Violence, and Insecurity in Nigeria: The Niger Delta in Perspective.” Occasional Paper No. 20. Geneva: Small Arms Survey.

Hegre, H., G. Østby, and C. Raleigh. 2009. "Poverty and Civil War Events: A Disaggregated Study of Liberia.” Journal of Conflict Resolution. Vol. 53, No. 4, pp. 598-623. http://dx.doi.org/10.1177/0022002709336459

Hendrix, C.S. and S.M. Glaser. 2007. "Trends and Triggers: Climate, Climate Change and Civil Conflict in Sub-Saharan Africa.” Political Geography. Vol. 26, No. 6, pp. 695-715. http://dx.doi.org/10.1016/j.polgeo.2007.06.006

Higazi, A. 2013. "Rural Insecurity on the Jos Plateau, Nigeria: Livelihoods, Land, and Religious Reform among the Berom, Fulani, and Hausa.” Oxford: Nigeria Research Network.

Hunt, J.T. 2006. The Politics of Bones: Dr. Owens Wiwa and the Struggle for Nigeria's Oil. Toronto: McClelland \& Stewart.

Jones-Casey, K. and A. Knox. 2011. "Farmer-Herder Conflicts in Mali." Focus on Land in Africa. World Resources Institute and LandesaRural Development Institute. www.focusonland.com/download/51dda6a62a68d/ [accessed 15 March 2015].

Justino, P., T. Brück, and P. Verwimp, eds. 2013. A Micro-Level Perspective on the Dynamics of Conflict, Violence, and Development. New York: Oxford University Press. http://dx.doi.org/10.1093/acprof:oso/978019966459 7.001.0001

Last, J.M., ed. 2001. A Dictionary of Epidemiology. 4th ed. New York: Oxford University Press.

Lindgren, G. 2005. "The Economic Costs of Civil Wars.” Paper presented at the 9th Annual International Conference on Economics and Security, Bristol, UK. http://carecon.org.uk/Conferences/Conf2005/Papers/Lind gren.pdf [accessed 15 March 2015].

Maystadt, J.-F., G. De Luca, P.G. Sekeris, and J. Ulimwengu. 2014. "Mineral Resources and Conflicts in DRC: A Case of Ecological Fallacy?” Oxford Economic Papers. Vol. 66, No. 3, pp. 721-749. http://dx.doi.org/10.1093/oep/gpt037

McDougal, T.L. 2011. "Insurgent Violence and the Rural-Urban Divide: The Case of Maoist India,” pp. 69-98

The Economics of Peace and Security Journal — ISSN 1749-852X — http://www.epsjournal.org.uk (C) EPS Publishing, 2015. All rights reserved. For permissions, email: ManagingEditor@epsjournal.org.uk 
in R. Caruso, ed. Ethnic Conflicts, Civil War, and Cost of Conflict. Bingley, UK: Emerald Group. http://dx.doi.org/10.1108/S1572-8323(2011)0000017008

McDougal, T.L., T. Hagerty, L. Inks, C. Dowd, and S. Conroy. 2015. "Macroeconomic Benefits of Farmer-Pastoralist Peace in Nigeria's Middle Belt: An Input-Output Analysis Approach.” The Economics of Peace and Security Journal. Vol. 10, No. 1, pp. 66-77. http://dx.doi.org/10.15355/epsj.10.1.66

Mohammed, A.S. Undated. "The Impacts of Conflict on the Economy: The Case of Plateau State of Nigeria.” London: Overseas Development Institute.

Nigeria National Population Commission. 2006. “2006 Population and Housing Census: Priority Table III: Population Distribution by Sex, State, LGA \& Senatorial District.” Abuja, Nigeria.

Nigeria National Population Commission. 2013. “Nigeria Demographic and Health Survey Preliminary Report,” in Measures DHS, ed. DHS Preliminary Reports. Calverton, MD: ICF International.

Obi, C.I. 2010. “Oil Extraction, Dispossession, Resistance, and Conflict in Nigeria's Oil-Rich Niger Delta.” Canadian Journal of Development Studies. Vol. 30, Nos. 1-2, pp. 219-236. http://dx.doi:10.1080/02255189.2010.9669289

Odoh, S.I. and C.F. Chigozie. 2012. "Climate Change and Conflict in Nigeria: A Theoretical and Empirical Examination of the Worsening Incidence of Conflict between Fulani Herdsmen and Farmers in Northern Nigeria.” Arabian Journal of Business and Management Review. Vol. 2, No. 1, pp. 110-124.

Ogbuabor, J.E. and V.A. Malaolu. 2013. "Size and Causes of the Informal Sector of the Nigerian Economy: Evidence From Error Correction Mimic Model.” Journal of Economics and Sustainable Development. Vol. 4, No. 1, pp. 85-103.

Onuoha, F.C. 2010. “The Islamist Challenge: Nigeria’s Boko Haram Crisis Explained.” African Security Review. Vol. 19, No. 2, pp. 54-67. http://dx.doi.org/10.1080/10246029.2010.503061

Sayne, A. 2011. "Climate Change Adaptation and Conflict in Nigeria.” Special Reports. Vol. 274. Washington, D.C.: U.S. Institute of Peace.

Sulaiman, A., M.R. Ja`afar-Furo, M. Nasiru, U. Haruna, and J.E. Ochi. 2011. "Farmers Socio-economic Factors Influencing Resource Use Conflicts in a Typical Fadama Area in Nigeria: A Focus on Bauchi State." Trends in Agricultural Economics. Vol. 4, pp. 58-64. http://dx.doi:10.3923/tae.2011.58.64

Tollefsen, A.F. 2012. "Disaggregating the Conflict Trap: A Spatial Analytical Approach.” Paper presented at the 12th Annual Jan Tinbergen Eurpoean Peace Science Conference. Berlin, Germany.

Watts, M. 2007. "Petro-Insurgency or Criminal Syndicate? Conflict and Violence in the Niger Delta." Review of African Political Economy. Vol. 34, No. 114, pp. 637-660. http://dx.doi.org/10.1080/03056240701819517

World Bank. 2011. World Development Report 2011: Conflict, Security, and Development. Washington, D.C.: World Bank.

World Bank. (2014). World Development Indicators. Washington, D.C.: World Bank.

\section{Appendix}

This appendix presents the calculation of the sample size, first stage methodology, and second stage methodology.

\section{Sample size calculation}

Table A.1: Sample size requirements for different values of $\mathbf{s d}_{\mathrm{i}}$

\begin{tabular}{cr}
$\begin{array}{c}\text { Presumed } \\
\text { sd }\end{array}$ & \multicolumn{1}{c}{$n$} \\
& \\
0.25 & 854 \\
0.30 & 1,229 \\
0.35 & 1,673
\end{tabular}

The standard sample size $(n)$ calculation for determining a difference in the mean values of an indicator between two groups $(1,2)$ is given as:

$$
n=\frac{1}{r} D \frac{\left[\left(Z_{1}+Z_{2}\right)^{2}\left(s d_{1}+s d_{2}\right)^{2}\right]}{\left(X_{1}+X_{2}\right)^{2}},
$$

where $r$ is the response rate, $D$ is the design effect, $Z_{i}$ is the indicator's Z-score for group $i, s d_{i}$ is the indicator's standard deviation for group $i$, and $X_{i}$ is the value of the mean value of the indicator for group $i$. For the purposes of the present calculation, we assumed $r=0.9, D=2, Z_{1}=Z_{2}=1.96$, and $X_{1}-$ $\mathrm{X}_{2}=0.1$. We calculate sample size for three different standard deviations: $\operatorname{sd}_{1}=\mathrm{sd}_{2}=(0.25,0.30,0.35)$. The sample size results are given in Table A.1. Conservatively, an $n$ of 1,500 should suffice. These calculations are in line with the CONCUR baseline report, which was based on a survey originally designed to have 1,350 respondents (at the individual level).

\section{First stage}

Without the benefit of the Enumeration Areas (EAs) used by the Nigerian DHS, we use LGAs as Primary Sampling Units. LGAs with population densities greater than 700 persons per $\mathrm{km}^{2}$ were considered urban, and otherwise the LGA was considered rural. This cut point was determined by examining the histogram of LGA population densities (available from the authors), which reveals that the bulk of LGAs in the study states have population densities less than 700 persons per $\mathrm{km}^{2}$, with a limited number of urban centers rising to around 6,500 persons per $\mathrm{km}^{2}$. We also spot-checked LGAs with populations 
just above and just below the cut point using Google Earth. Indeed, it did seem to be that LGAs below the cut point (e.g., Kaura, Kaduna; Kudan, Kaduna) do not have large urban centers, while those above the cut point (e.g., Makurdi, Benue) usually hosted a large, urban center.

A table giving the specific breakout of the sampling frame's first stage is available from the authors. We chose to use 40 clusters and 40 households per cluster, as we were aiming for $n>1,500[1,500 \mathrm{HH} /(40 \mathrm{HH} /$ cluster $)=37.5$ clusters $]$. The sampling interval accordingly is given as $\mathrm{SI}=\mathrm{N} /$ clusters $=13.54 \mathrm{~m} / 40=338,505$. Using a random number generator, we determined the random start at 230,098. A column in the table, Attributed Clusters, gives the total number of clusters that should be selected in each LGA.

Mercy Corps administered the survey in nine program communities, as described in our CONCUR Baseline Report. In every case, these purposively sampled observations came from a randomly identified LGA (via Stage 1) and are noted with a dummy variable. In one case, a Mercy Corps program site was selected randomly in both Stage 1 and Stage 2 of the sampling process.

\section{Second stage}

Mercy Corps has large-format (small-scale), GIS-generated maps of each state with LGAs and community locations identified, which were used to draw approximate centroids on each LGA, spin a bottle to set a random direction, count the number of communities in a 20-degree arc radiating from the center to the farthest point in the LGA, and finally use a random number generator to choose a community corresponding to a number between 1 and the total count of communities in that swathe.

Once particular communities were selected, a similar "spin the bottle" method was used to identify households with the community. A spin of the bottle from the community's center point indicates a random direction. Following this radius toward the edge of the community yields a certain number of households, from which a random number generator selects a starting point. Arbitrary rules for sequence can then dictate the next households to be selected. A common method is just to find the nearest, non-sampled house. However, that method tends to draw the researcher closer to the center of town (because houses are more closely spaced toward the center than away from it), and it violates the ideal tenet in sampling to make the selection of any given observation independent of all others. Because the survey will be operating at only the household (and not the individual) level, a Kish Grid or other method of selecting a respondent is not necessary. 